\title{
Large-sized phytoplankton sustain higher carbon- specific photosynthesis than smaller cells in a coastal eutrophic ecosystem
}

\author{
Pedro Cermeñó ${ }^{1, *}$, Emilio Marañón ${ }^{1}$, Jaime Rodríguez² ${ }^{\text {, Emilio Fernández }}{ }^{1}$ \\ ${ }^{1}$ Departamento de Ecología y Biología Animal, Facultad de Ciencias del Mar, Universidad de Vigo, 36310 Vigo, Spain \\ ${ }^{2}$ Departamento de Ecología y Geología, Universidad de Málaga, Campus de Teatinos, 29071 Málaga, Spain
}

\begin{abstract}
Size-fractionated, carbon-specific photosynthesis by natural phytoplankton assemblages has been analysed during a full annual cycle in a coastal, productive ecosystem. We observed high variability in the carbon-specific photosynthetic rates by the different phytoplankton size fractions. In surface waters, under high irradiance levels, large-sized phytoplankton showed consistently higher carbon-specific photosynthetic rates than small-sized cells. We suggest the possibility that interspecific differences in acquisition and use of light and nutrients account for this pattern. Under light-limited conditions at the bottom of the euphotic layer, differences in the carbon-specific photosynthesis between size fractions were lower or disappeared, which was likely due to the package effect on larger cells. Our results show that when the whole phytoplankton community is analysed, the relationship between carbon-specific photosynthesis and cell size is variable. Moreover, a higher carbon-specific photosynthesis by larger phytoplankton might represent an ecophysiological basis to explain their dominance in resource-rich environments.
\end{abstract}

KEY WORDS: Phytoplankton · Cell size $\cdot$ Carbon-specific photosynthesis $\cdot$ Eutrophic ecosystem

\section{INTRODUCTION}

Cell size has long been established in aquatic microbial ecology as a major controlling factor of community structure and metabolism (Chisholm 1992, Rodríguez 1994, Li 2002). Fenchel (1974), Banse (1976) and Taguchi (1976) were among the first to report a strong relationship between a specific metabolic rate and phytoplankton cell size. This relationship is commonly expressed by the equation, $R=a V^{b}$, where $R$ is the biomass-specific metabolic rate, $V$ is cell size (biovolume or carbon biomass), $a$ is a group-specific constant or rate coefficient and $b$ is the size-scaling parameter. Early experimental observations led to the conclusion that $b$ takes a constant value of around -0.25 (Hemmingsen 1960; see review by Peters 1983). However, the numerical value of this parameter continues to be a matter of debate. Several authors have argued that when interspecific variability is taken into account the relationship between phytoplankton cell size and growth rate becomes weaker (Banse 1982, Blasco et al. 1982, Chisholm 1992) and highly variable (Tang 1995). In addition, numerous studies in productive environments have reported instances of larger phytoplankton sustaining higher rates of chlorophyll a-normalised photosynthesis than smaller cells (i.e. Legendre et al. 1993, Tamigneaux et al. 1999, Hashimoto \& Shiomoto 2002, among others). Unfortunately, the interpretation of the chlorophyll a-normalised photosynthesis depends on the carbon-to-chlorophyll a ratio, which has been reported to vary with environmental conditions, cell size and phyletic affiliation (Taylor et al. 1997, Finkel et al. 2004). It is therefore necessary to obtain simultaneous measurements of size-fractionated photosynthesis and carbon biomass in order to determine the carbon-specific phytoplankton photosynthesis, which is analogous to a specific growth rate (e.g. Kirchman 2002). However, there are relatively 
few measurements of the size-fractionated, carbonspecific photosynthesis by natural phytoplankton assemblages, and, to the best of our knowledge, no previous study has addressed this variable throughout an entire annual cycle.

It is well established that biomass and production of small-sized cells tend to remain relatively constant, whereas large-sized cells bloom whenever adequate conditions of light and nutrients exist (see review by Chisholm 1992). Any increase in the biomass of smallsized phytoplankters is rapidly followed by an increase in the biomass and activity of the small herbivores, which exert a strict grazing control upon these populations (Banse 1992, Kiørboe 1993). In contrast, large phytoplankton are grazed by mesozooplankters with longer generation times than those of phytoplankton. Consequently, the uncoupling between prey (phytoplankton) and predators (zooplankton) has been proposed to explain why large phytoplankton become dominant in resource-saturated environments (Kiørboe 1993). However, there are a few reports showing that large-sized phytoplankton can attain higher growth rates than small-sized phytoplankton under natural conditions, particularly when nutrient concentrations are high (Furnas 1991, Frenette et al. 1996, Crosbie \& Furnas 2001, Jochem 2003). This raises the possibility that, in addition to trophic mechanisms, purely physiological factors could also explain the dominance of large-sized phytoplankton under favourable conditions for growth.

In this work, we have used a combination of flow cytometry and microscopy image analysis to determine the carbon biomass of the microbial autotrophic community during a full annual cycle. Simultaneously, we have also determined the photosynthesis rate by phytoplankton in the picoplankton $(<2 \mu \mathrm{m})$, small nanoplankton (2 to $5 \mu \mathrm{m}$ ), large nanoplankton (5 to $20 \mu \mathrm{m})$ and microplankton $(>20 \mu \mathrm{m})$ size ranges. Our study system, the Ría de Vigo (NW Iberian Peninsula), is a coastal embayment characterised by a very dynamic, wind-driven horizontal circulation (ÁlvarezSalgado et al. 2001). As a result of the ever changing hydrodynamical forcing, phytoplankton assemblages in the Ría de Vigo display a high degree of variability in plankton size-structure and primary production (Tilstone et al. 1999), which makes it an excellent testing ground for hypotheses on the relationship between cell size and metabolic rates. Our main goals were to determine the temporal and vertical variability in size-fractionated, carbon-specific photosynthesis by coastal phytoplankton assemblages during a full annual cycle and to test the hypothesis that, under conditions favourable for growth, large phytoplankton are capable of sustaining higher carbon-specific photosynthetic rates than smaller phytoplankton.

\section{MATERIALS AND METHODS}

Sampling. A total of 25 visits to a central station in the Ría de Vigo $\left(42^{\circ} 14.09^{\prime}\right.$ N, $\left.8^{\circ} 47.18^{\prime} \mathrm{W}\right)$ were carried out from July 2001 to July 2002. Typically, sampling was completed between 07:00 and 09:00 h. On each visit, we recorded vertical profiles (0 to $40 \mathrm{~m})$ of temperature and conductivity with a SBE 25 CTD probe. The vertical distribution of photosynthetically active irradiance (PAR, 400 to $700 \mathrm{~nm}$ ) was measured with a spherical quantum sensor connected to a LiCor datalogger. Water samples for chemical and biological measurements were collected using single 51 Niskin bottles. Samples for the analysis of dissolved inorganic nutrients (nitrate, nitrite, silicate, phosphate and ammonium) were obtained from 0, 5, 10, 15, 20 and $30 \mathrm{~m}$. These samples were immediately frozen and stored at $-20^{\circ} \mathrm{C}$ until they were analysed in the laboratory following the methods described in Grasshoff et al. (1999).

Size-fractionated chlorophyll $a$ and carbon biomass. For determination of the size-fractionated chlorophyll $a$ (chl a) concentration, $250 \mathrm{ml}$ samples (2 replicates per sample) were filtered sequentially through 20, 5, 2 and $0.2 \mu \mathrm{m}$ polycarbonate filters, using low vacuum pressure $(<100 \mathrm{~mm} \mathrm{Hg})$. Filters were stored frozen at $-80^{\circ} \mathrm{C}$ until further analysis, which took place within 4 mo of sampling. Pigment was extracted by placing the filters in $90 \%$ acetone during $12 \mathrm{~h}$ in the dark. Chl a concentration was determined fluorometrically, using the nonacidification technique of Welschmeyer (1994), on a TD-700 fluorometer that had been calibrated with pure chl a (Sigma).

We identified and obtained estimates of cell size and the abundance of pico- and nanophytoplankton ( 0.2 to $12 \mu \mathrm{m}$ equivalent spherical diameter, ESD) by flow cytometry, on the basis of the fluorescence signals and forward- and side-light scatter (FSC and SSC, respectively). For flow cytometry analyses, $10 \mathrm{ml}$ samples were preserved with glutaraldehyde $(1 \%$ $\mathrm{v} / \mathrm{v}$ ) and stored in liquid nitrogen until further analysis, which took place within 2 to $3 \mathrm{wk}$. Samples were analysed with a FACScan (Becton Dickinson) flow cytometer following the protocols in Rodríguez et al. (1998). For the image analysis of larger cells under the microscope, $100 \mathrm{ml}$ samples were preserved with $(1 \%$ $\mathrm{v} / \mathrm{v})$ Lugol's solution. After sedimentation of a subsample (10 to $25 \mathrm{ml})$, cells were counted and measured at $\times 100$ and $\times 200$ on a Leitz Fluovert inverted microscope connected to a VIDS V (Analytical Measuring Systems) image analysis system. Finally, cell volume was estimated as the revolution volume according to an ellipsoidal shape. Analytical subranges for flow cytometry and image analysis were approximately 0.7 to 12 and 8 to $60 \mu \mathrm{m}$ ESD, respec- 
tively. Flow cytometry and image analysis analytical sub-ranges were coupled in order to obtain a continuous size-abundance spectrum for the whole autotrophic plankton community (see Rodríguez et al. 1998 for further details). We also counted cells within diatom chains separately, and determined the length of their major and minor cell axes, as well as the number of cells per chain.

Individual cell carbon (C) biomass was estimated from cell volume $(V)$, according to empirical volumeto-carbon conversion factors. The choice of adequate volume-to-carbon conversion factors is critical in obtaining reliable estimates of phytoplankton $\mathrm{C}$ biomass. A major source of uncertainty in the application of these conversion factors to natural phytoplankton assemblages stems from the different relationships reported for different taxonomic groups. For instance, dinoflagellates are more dense than diatoms (MendenDeuer \& Lessard 2000). Among diatoms, the C content per unit $V$ depends on the presence of vacuoles (Strathmann 1967). In addition, great uncertainty exists in dealing with cell shrinkage as a result of fixation procedures (Montagnes et al. 1994, MendenDeuer \& Lessard 2000). Finally, different factors have been reported for picophytoplankton groups such as Synechococcus or picoeukaryotes (Verity et al. 1992). In the present study, estimates of picophytoplankton $\mathrm{C}$ were obtained using the equation: pg $\mathrm{C}$ cell $^{-1}=$ $0.433 V^{0.863}$ (Verity et al. 1992). Nano- and microphytoplankton $\mathrm{C}$ estimates were obtained using the following equations: $\mathrm{pg} \mathrm{C} \mathrm{Cell}^{-1}=0.288 \mathrm{~V}^{0.811}$ for diatoms and pg $\mathrm{C}$ cell $^{-1}=0.216 V^{0.939}$ for other phytoplankton (Menden-Deuer \& Lessard 2000). We restricted the use of Menden-Deuer and Lessard's conversion factors to the nano- and microplankton size ranges, because when applied to picoplankton it consistently yielded C-to-chl a ratios that were unrealistically low (2 to $10 \mathrm{mg} \mathrm{C} \mathrm{mg}^{-1} \mathrm{chl}$ a), which strongly suggests that picophytoplankton $\mathrm{C}$ was underestimated. Finally, C biomass for each size category was calculated by multiplying cell concentration by cell $\mathrm{C}$, thus generating size spectra of $C$ biomass (see Fig. 2). From these spectra, we assigned the $\mathrm{C}$ biomass to 4 size fractions, 0.2 to $2 \mu \mathrm{m}$ (picophytoplankton), 2 to $5 \mu \mathrm{m}$ (small nanophytoplankton), 5 to $20 \mu \mathrm{m}$ (large nanophytoplankton) and $>20 \mu \mathrm{m}$ (microphytoplankton). The C content of cells within chains was included in the $>20 \mu \mathrm{m}$ size class.

Flow cytometry and image analysis allowed us to define different analytical populations that were related to different phytoplankton groups. Using flow cytometry we defined Synechococcus spp., cytometry population 1 (picoeukaryotes), cytometry population 2 (mainly nanoflagellates) and Cryptophytes. Image analysis allowed us to identify diatoms and other phytoplankters, mainly dinoflagellates.
Size-fractionated photosynthesis. Size-fractionated photosynthetic rates were determined by the ${ }^{14} \mathrm{C}$ uptake technique. Four $75 \mathrm{ml}$, acid-cleaned polystyrene bottles (3 light and 1 dark bottle) were filled with water from surface, 10 and $20 \mathrm{~m}$ depths. Each bottle was inoculated with $\sim 370 \mathrm{kBq}(10 \mu \mathrm{Ci})$ of $\mathrm{NaH}^{14} \mathrm{CO}_{3}$ and then incubated for $2 \mathrm{~h}$ starting at noon. We used an incubator equipped with a set of blue and neutraldensity plastic filters that reproduced the irradiance conditions at the original depths where the samples had been collected. A system of re-circulating water passing through 2 refrigerators was used to maintain incubation temperature within $1.5^{\circ} \mathrm{C}$ of the original temperature at each sampling depth.

At the end of the incubations, samples were sequentially filtered through 20,5, 2 and $0.2 \mu \mathrm{m}$ polycarbonate filters under low-vacuum pressure $(<100 \mathrm{~mm} \mathrm{Hg})$. Inorganic carbon on the filters was removed by exposing the filters to $\mathrm{HCl}$ fumes overnight. After removal of inorganic ${ }^{14} \mathrm{C}$, filters were placed into scintillation vials to which $4 \mathrm{ml}$ of scintillation cocktail was added. Radioactivity was measured on a 1409-012 Wallac scintillation counter that used an internal standard for quenching correction.

\section{RESULTS}

\section{Hydrographic variability and biomass size spectra}

The Ría de Vigo shows a marked hydrographic seasonality accompanied by important changes in the size structure of phytoplankton communities. This system is very productive as a result of the high nutrient inputs that occur all year round, either through upwelling, continental runoff or 'in situ' remineralisation (Nogueira et al. 1997). The temporal and vertical variability of temperature, nitrate concentration and photosynthetic rates from July 2001 to July 2002 in the Ría de Vigo has been recently described (Marañón et al. 2004). Summer stratification was characterised by high temperatures $\left(>16^{\circ} \mathrm{C}\right)$, low nitrate $\left(<0.5 \mu \mathrm{mol} \mathrm{l}^{-1}\right)$, but high ammonia concentrations $\left(>3.5 \mu \mathrm{mol} \mathrm{l^{-1 } )}\right.$ in surface waters (Fig. 1), and a sub-surface chl a maximum ( 3 to $6 \mathrm{mg} \mathrm{m}^{-3}$ ) at around $10 \mathrm{~m}$ depth. From 5 October 2001 to 30 March 2002, we found vertical mixing and high nitrate concentrations (>4 $\mu \mathrm{mol} \mathrm{l}^{-1}$ ) throughout the water column. During this period, water column temperature varied between 12 and $18^{\circ} \mathrm{C}$, and chl a concentrations were in the range from 0.5 to $1.5 \mathrm{mg} \mathrm{m}^{-3}$. Summer upwelling gave way to intermittent intrusions of cold $\left(12^{\circ} \mathrm{C}\right)$ and nitrate-rich (>9 $\mathrm{\mu mol} \mathrm{l}^{-1}$ ) sub-surface waters. During this period, chl a concentrations were typically $>5 \mathrm{mg} \mathrm{m}^{-3}$ in the upper layer. 

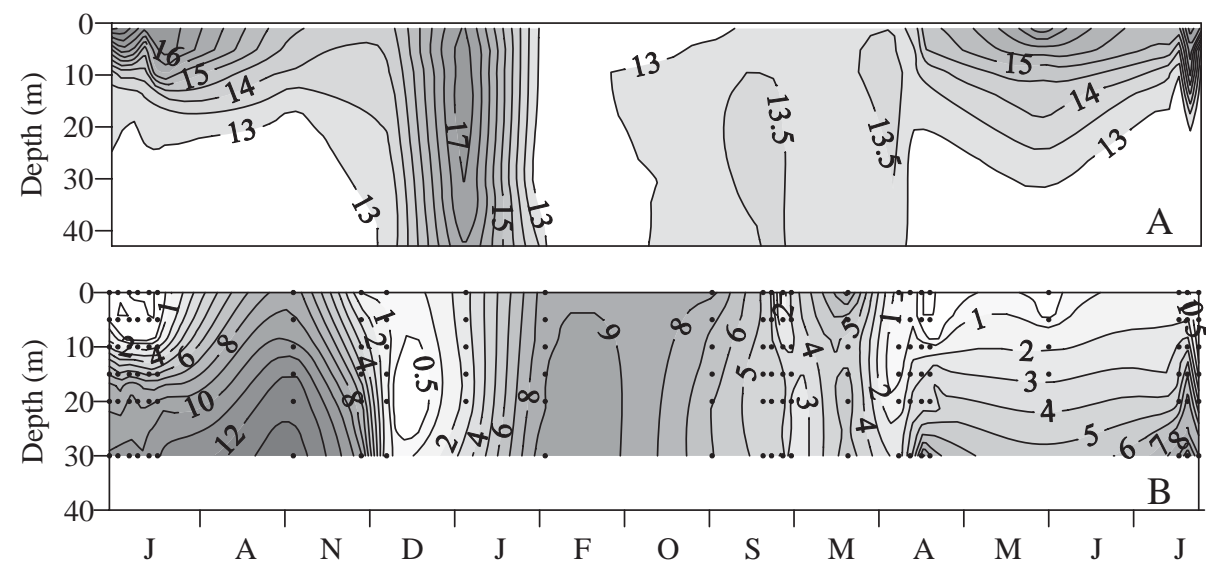

Fig. 1. Vertical and temporal distributions of (A) temperature and (B) nitrate concentrations

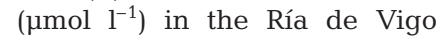
from July 2001 to July 2002
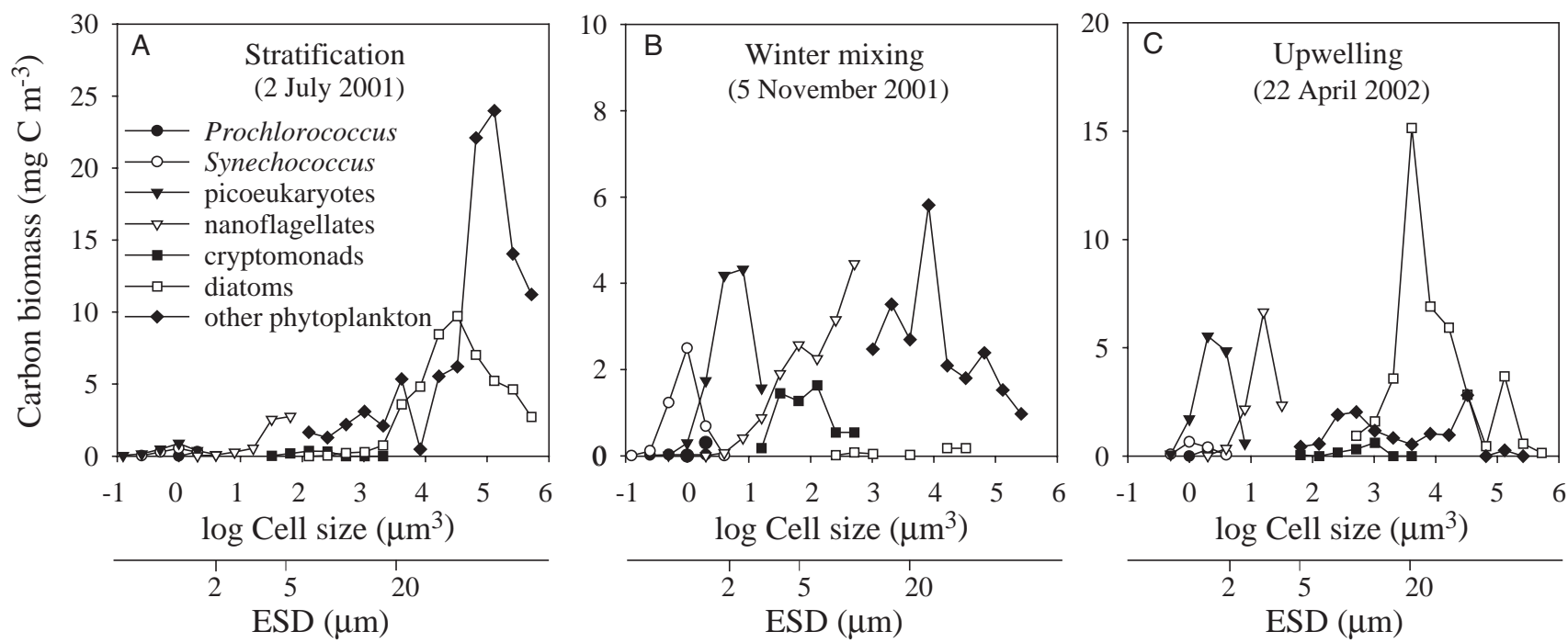

Fig. 2. Representative biomass size spectra of surface samples for 3 different oceanographic conditions: (A) summer stratification, (B) winter mixing, and (C) upwelling. Symbols indicate taxonomic groups identified by flow cytometry and microscopy image analysis (ESD: equivalent spherical diameter)

Our size spectra of $\mathrm{C}$ biomass indicate that as cell size increases the taxonomic composition changes from small cyanobacteria, mainly Synechococcus sp., to large dinoflagellates and diatoms (Fig. 2). Although we did not determine the taxonomic composition at the species level, our analysis allowed us to observe that the overall taxonomic pattern, in terms of presence of main groups, did not change significantly either during the different oceanographic conditions (Fig. 2) or over depth (data not shown). However, we did find a stronger dominance of larger cells during conditions of enhanced phytoplankton biomass, such as summer stratification and upwelling events (Fig. 3A). In these cases, $>40 \%$ of total autotrophic $\mathrm{C}$ would be accounted for by the $>20 \mu \mathrm{m}$ size fraction. In contrast, typical relative contributions of microphytoplankton to total autotrophic C during winter were $<15 \%$ when total C

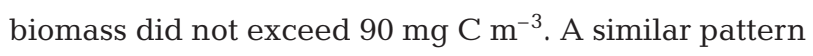
was observed for size-fractionated chl a (Fig. 3B). On average, during stratification and upwelling, diatoms accounted for $17 \pm 8$ and $43 \pm 21 \%$ of the total $\mathrm{C}$ biomass, respectively (data not shown). In winter, the contribution of diatoms decreased to about $2.3 \pm 1.8 \%$, and a higher contribution was mainly accounted for by picocyanobacteria, picoeukaryotes and nanoflagellates.

\section{Carbon-specific photosynthetic rates}

According to the vertical profiles of temperature and density observed on each visit to the sampling station, we grouped our determinations of the size-fractionated, C-specific photosynthetic rate into 3 contrasting oceanographic conditions: summer stratification, win- 
ter mixing and upwelling. All observations included in the summer stratification period were carried out from 2 to 19 July 2001. The monthly measurements taken in October, November and December 2001 and January and March 2002, plus the observations obtained on 18 February as part of the February intensive sampling, were used to characterise the phytoplankton community during conditions of winter mixing. Finally, the upwelling phase included the measurements carried out during the April and July intensive sampling periods, plus those obtained during the monthly sampling in May 2002. In all these oceanographic conditions, surface samples showed a consistent pattern in the size-fractionated, C-specific photosynthetic rates, with significantly higher values $\left(>0.2 \mathrm{~h}^{-1}\right)$ in the microplankton size fraction than in the $<20 \mu \mathrm{m}$ size fractions
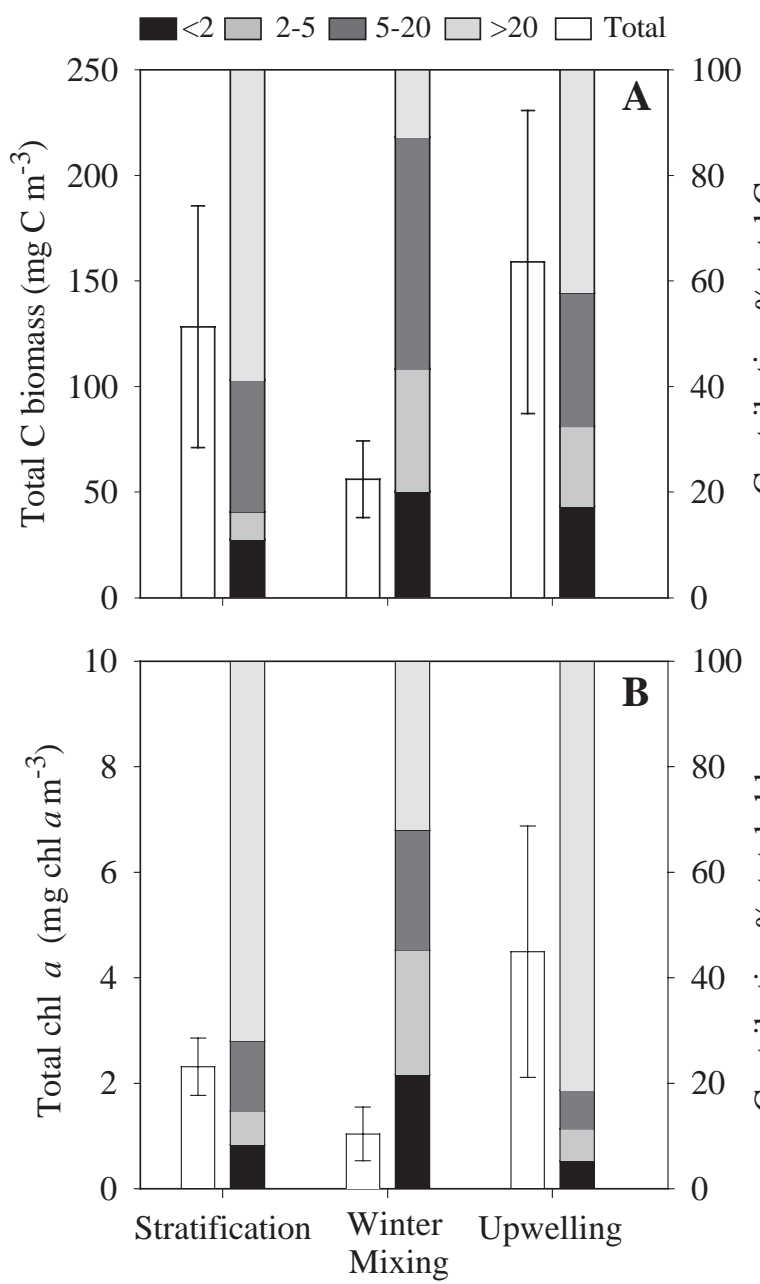

Fig. 3. (A) Total phytoplankton carbon and (B) chlorophyll a and the relative contributions $(\%)$ of picoplankton $(<2 \mu \mathrm{m})$, small nanoplankton ( 2 to $5 \mu \mathrm{m}$ ), large nanoplankton (5 to $20 \mu \mathrm{m})$ and microplankton $(>20 \mu \mathrm{m})$ to (A) total carbon and (B) chlorophyll a of surface phytoplankton assemblages for 3 different oceanographic conditions
(Fig. 4). In sub-surface waters, C-specific photosynthetic rates decreased relative to surface values, especially in the microplankton size class, and, excluding upwelling conditions, no significant differences were obtained between size fractions (Fig. 4).
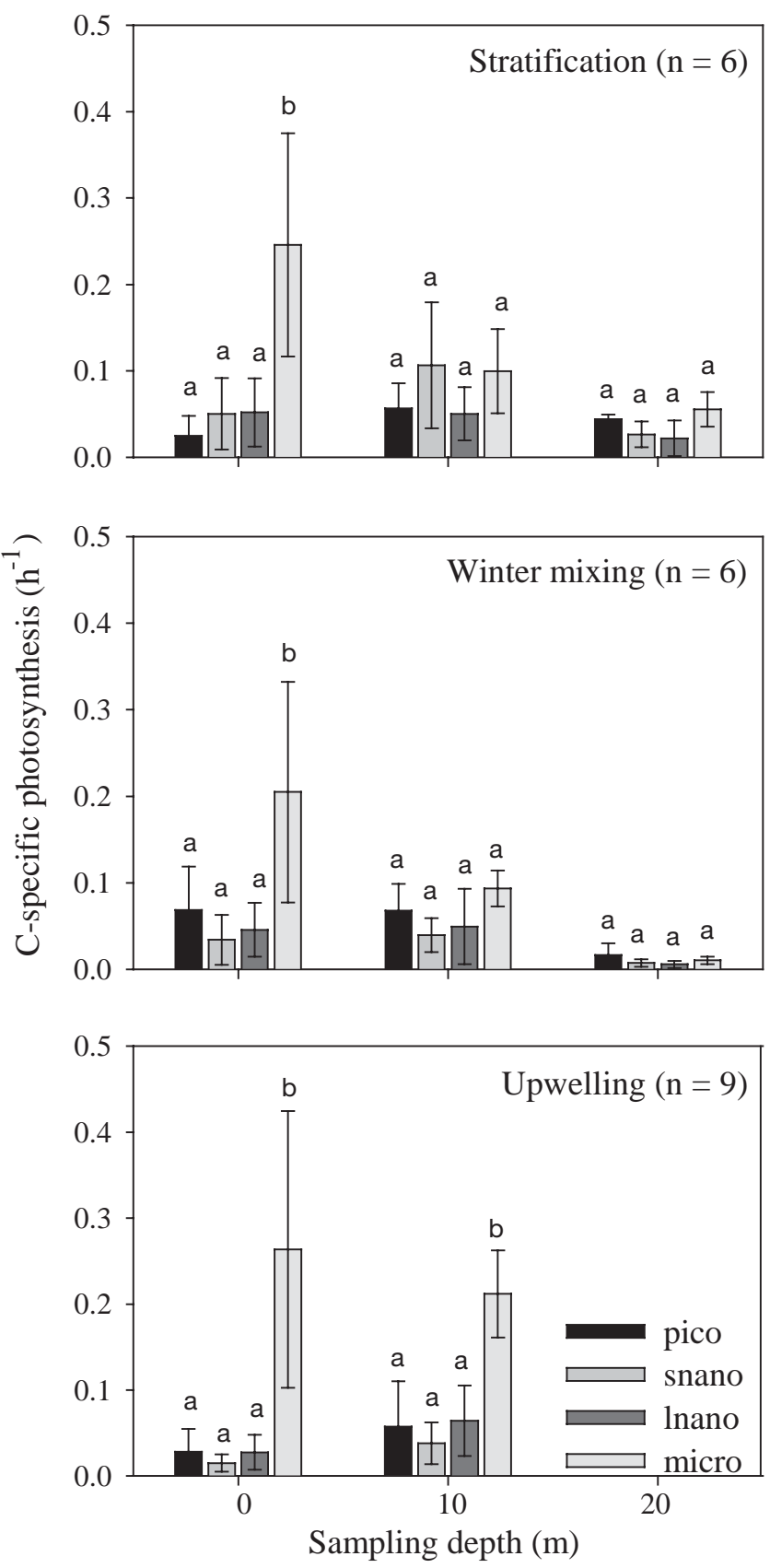

Fig. 4. Mean $( \pm \mathrm{SD})$ carbon-specific photosynthesis $\left(\mathrm{h}^{-1}\right)$ for picophytoplankton (pico), small nanophytoplankton (snano), large nanophytoplankton (lnano) and microphytoplankton (micro) at the surface (left bars), $10 \mathrm{~m}$ (middle bars) and $20 \mathrm{~m}$ (right bars), during 3 different oceanographic conditions. Means that are not significantly different (Kruskal-Wallis and a posteriori Mann-Whitney tests) are labelled with the same letter (n: number of samples) 
A possible bias in our estimates of $\mathrm{C}$-specific photosynthesis lies in the reliability of the $\mathrm{C}$ estimates used (see 'Materials and methods'). For this reason, we recalculated the size-fractionated, C-specific photosynthesis for surface samples using different volumeto-carbon conversion factors reported in the literature. This sensitivity test allowed us to determine to what
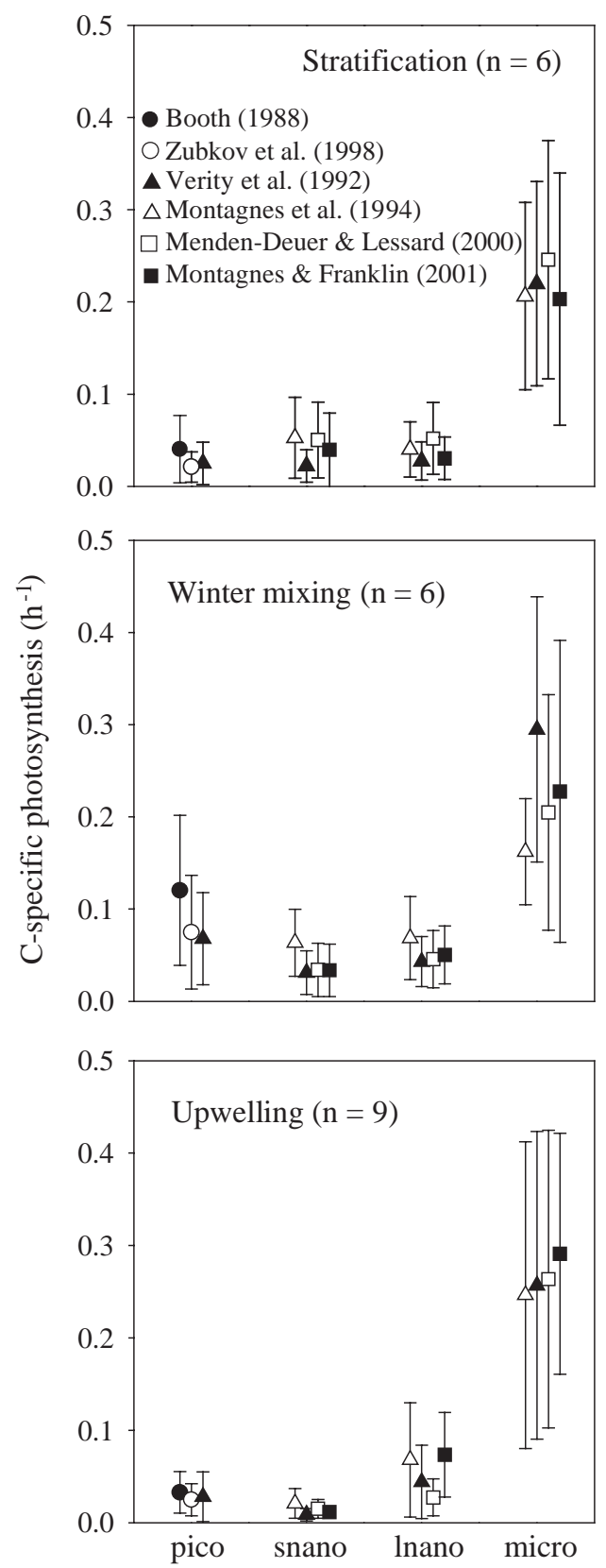

Size class

Fig. 5. Mean $( \pm \mathrm{SD})$ carbon-specific photosynthesis $\left(\mathrm{h}^{-1}\right)$ for surface phytoplankton on each size class sampled during 3 different oceanographic conditions. Symbols indicate the reference of the volume-to-carbon conversion factors used to calculate phytoplankton carbon (abbreviations as for Fig. 4) extent the choice of particular conversion factors could alter our conclusions (Fig. 5). In general, statistical analyses of the differences in C-specific photosynthesis between the different size-class combinations yielded the same results as those presented in Fig. 4. Only for winter samples and when using the conversion factors reported by Booth (1988) and Montagnes et al. (1994) for the pico- and microphytoplankton, respectively, did we fail to find significant differences in C-specific photosynthesis between these 2 size fractions (Mann-Whitney test, $\mathrm{p}>0.05$ ). Excluding these particular cases, we observed that irrespective of the conversion factors used, C-specific photosynthesis by $>20 \mu \mathrm{m}$ phytoplankton always exceeded that of the nano- and picophytoplankton (Kruskal-Wallis and a posteriori Mann-Whitney tests, p < 0.05, Fig. 5).

Similar to the pattern obtained for the size-fractionated, C-specific photosynthesis in surface waters, large-sized phytoplankton also showed higher chl aspecific photosynthetic rates than small-sized fractions. For instance, the surface photosynthesis-to-chl a ratio during summer stratification was $1.6 \pm 1,1.9 \pm 1$, $4 \pm 1.3$ and $6.6 \pm 1.9 \mathrm{mg} \mathrm{C} \mathrm{mg}^{-1} \mathrm{chl} \mathrm{a} \mathrm{h}^{-1}$ for pico-, small nano-, large nano- and microphytoplankton, respectively. During winter mixing, we obtained chl a-specific photosynthetic rates of $2.6 \pm 1.6,1.9 \pm 1.5,4.4 \pm 2.2$ and $4.8 \pm 2.2 \mathrm{mg} \mathrm{C} \mathrm{mg}^{-1} \mathrm{chl} \mathrm{a} \mathrm{h}^{-1}$ for pico-, small nano, large nano- and microphytoplankton, respectively. Finally, during upwelling the chl a-specific photosynthetic rates were $2.2 \pm 1.5,1.2 \pm 0.6,2.7 \pm 2$ and $5.9 \pm$ $3.2 \mathrm{mg} \mathrm{C} \mathrm{mg}^{-1} \mathrm{chl} \mathrm{a} \mathrm{h}^{-1}$ for pico-, small nano-, large nano- and microphytoplankton, respectively. Consistent with the vertical pattern obtained for the Cspecific photosynthesis, the photosynthesis-to-chl a ratio decreased with depth, and lower differences were observed between size fractions. Thus, although chl a-specific photosynthesis cannot directly be interpreted as an estimate of phytoplankton growth, these values provide further evidence that in surface waters large phytoplankton have higher photosynthetic efficiency than smaller cells.

Phytoplankton increase their intracellular pigment concentration in response to decreasing growth irradiance (Taylor et al. 1997). This variability in pigment concentration is usually reflected in the C-to-chl a (C:chl a) ratio, which represents an index of phytoplankton acclimation to different growth irradiances. Thus, using our estimates of phytoplankton $\mathrm{C}$ biomass and the chl a measurements, we also calculated the size-fractionated C:chl a ratio for the same 3 oceanographic situations. We assessed the differences in the size-fractionated C:chl a ratios over depth. During summer stratification, we observed significant differences in the C:chl a ratios between the surface and $20 \mathrm{~m}$ depths (Mann-Whitney tests, $\mathrm{p}<0.05$, see 
Table 1. Size-fractionated carbon-to-chlorophyll a ratios $\left(\mathrm{mg} \mathrm{C} \mathrm{mg}^{-1} \mathrm{chl}\right.$ a) at different depths during 3 distinct oceanographic conditions. For each oceanographic condition and size fraction, depth means that are not significantly different (Kruskal-Wallis and a posteriori Mann-Whitney tests) are labelled with the same letter

\begin{tabular}{|c|c|c|c|c|}
\hline Depth (m) & Picophytoplankton & Small nanophytoplankton & Large nanophytoplankton & Microphytoplankton \\
\hline \multicolumn{5}{|c|}{ Stratification } \\
\hline Surface & $75.8 \pm 39.3^{\mathrm{a}}$ & $43.6 \pm 9.1^{\mathrm{a}}$ & $97.2 \pm 31.6^{\mathrm{a}}$ & $33.3 \pm 12.6^{\mathrm{a}}$ \\
\hline 10 & $29.8 \pm 20.9^{b}$ & $19.5 \pm 9.8^{b}$ & $55.3 \pm 28.5^{b}$ & $43 \pm 32.4^{\mathrm{a}}$ \\
\hline 20 & $12.1 \pm 4.8^{\mathrm{b}}$ & $21.3 \pm 10.4^{\mathrm{b}}$ & $51 \pm 36.1^{b}$ & $13.4 \pm 4.8^{\mathrm{b}}$ \\
\hline \multicolumn{5}{|c|}{ Winter mixing } \\
\hline Surface & $49.6 \pm 32.7^{a}$ & $46.2 \pm 17.6^{\mathrm{a}}$ & $81.2 \pm 55.4^{\mathrm{a}}$ & $28.2 \pm 16.6^{a}$ \\
\hline 10 & $34.8 \pm 13.1^{\mathrm{a}}$ & $52.2 \pm 16.3^{\mathrm{a}}$ & $88.5 \pm 56.5^{\mathrm{a}}$ & $40.9 \pm 18.5^{a}$ \\
\hline 20 & $35.4 \pm 8.6^{\mathrm{a}}$ & $54.2 \pm 24.3^{\mathrm{a}}$ & $60.9 \pm 21.9^{a}$ & $40.5 \pm 22.2^{a}$ \\
\hline \multicolumn{5}{|l|}{ Upwelling } \\
\hline Surface & $125.4 \pm 46.9^{a}$ & $94.3 \pm 38.1^{\mathrm{a}}$ & $79.9 \pm 20.1^{\mathrm{a}}$ & $22 \pm 12.1^{\mathrm{a}}$ \\
\hline 10 & $93.3 \pm 58.7^{a}$ & $62.7 \pm 35.1^{\mathrm{a}}$ & $65.4 \pm 55.3^{\mathrm{a}}$ & $14.5 \pm 4.4^{\mathrm{a}}$ \\
\hline
\end{tabular}

Table 1), reflecting the increasing chl a cellular content in the populations acclimated to low light. In contrast, we did not observe any significant differences between depths, either during winter or the upwelling period. It is likely that during these periods the lack of vertical variability in the $C: c h l$ a ratios was due to the vertical mixing, which prevented any possible photoacclimation in phytoplankton assemblages.

The C:chl a ratio shows a large degree of variability, depending on growth irradiance, nutrient concentrations and taxonomic composition. However, this ratio usually falls within values in the range of from 10 to $150 \mathrm{mg} \mathrm{C} \mathrm{mg}^{-1} \mathrm{chl}$ a (Taylor et al. 1997). The C:chl a ratios obtained in this study are all within the range of those previously reported for other coastal areas (Scheafer \& Lewin 1984, Chang et al. 2003), or predicted by physiological models based on irradiance and nutrient conditions (Taylor et al. 1997). This fact, together with the expected observation of a decrease in C:chl a ratios over depth during stratification, gives us further confidence in the validity of our phytoplankton $\mathrm{C}$ estimates.

\section{DISCUSSION}

\section{Size-scaling physiological factors and ecological implications}

Throughout our annual survey, we consistently found that surface phytoplankton in the $>20 \mu \mathrm{m}$ size fraction sustain higher C-specific photosynthesis rates than smaller cells. In principle, this contrasts with theoretical models and empirical observations suggesting that an increase in cell radius decreases both solute exchange on a volume basis (Raven 1998, Raven \& Kübler 2002) and the optical absorption cross section, which is an estimate of light absorption efficiency per pigment content, referred to as the 'package effect' (Morel \& Bricaud 1981, Kirk 1983). In contrast to this, Stolte et al. (1994) reported that, in diatoms, nitrate uptake rates show a strong positive correlation with cell size under nutrient-pulsed conditions. Many works have indicated that certain phytoplankters, in particular diatoms, have a special ability to store nutrients in vacuoles, which might allow them to grow faster in nutrient-depleted conditions by maximising photosynthesis during favourable light periods (Geider et al. 1986, Raven 1997). In this sense, several studies have described how nutrient-uptake rates frequently exceed the requirements imposed by cellular metabolic demands. This physiological mechanism, known as luxury uptake, is typically associated with vacuolated diatoms growing under intermittent upwelling conditions (Malone 1980, Raven 1997). Similarly, a recent study suggests that large-sized phytoplankton, mainly diatom groups, may have higher light utilisation efficiency than smaller algae (Hashimoto \& Shiomoto 2002).

Differences in the maximum potential growth rates have been reported in relationship to the specific composition of the phytoplankton community (Chan 1980, Furnas 1990). A number of factors exist explaining variability between specific groups, such as differences in C:chl a ratios and absorption cross sections (Falkowski et al. 1985). Distribution of chloroplasts in the cell appears to be a major factor in light acquisition, especially under light-limited conditions. In diatoms, chloroplasts are frequently organised in a thick layer close to the cytoplasm membrane. This allows them to maximise the cell surface to absorb light, whereas nutrients can be stored in large intracellular vacuoles (Paasche 1960). Thus, given that the taxonomic composition changes along the size spectrum of the phytoplankton communities, it is possible that differences in the $\mathrm{C}$-specific photosynthetic rates reported in 
this study represent differences between taxonomic groups rather than the effect of cell size per se.

Another important factor is the possibility that very small cells are prevented from increasing their scalable components (i.e. photosynthetic units) due to the necessity of maintaining a constant quota of nonscalable essential components (i.e. genome) within a very small cell volume (Raven 1998). This has important implications for the maximum growth rate because under conditions favourable for growth only large cells will be able to increase their intracellular quota of molecules involved in metabolic processes.

Our observations of a higher C-specific photosynthesis by large-sized phytoplankton may bear important implications for our understanding of phytoplankton size distribution in nature. It is well established that small herbivores exert a tight grazing control over the biomass of small-sized cells (Banse 1992). In contrast, the uncoupling between large-sized phytoplankton and mesozooplankon, with generation times larger than those of phytoplankton, appears to explain the dominance of large phytoplankton in resource-saturated environments (Banse 1992, Kiørboe 1993). Although these trophic interactions are of unquestioned importance in marine ecosystems (Banse 1992), our analysis indicates that under favourable conditions for growth, namely high irradiance and nutrient concentrations, large-sized phytoplankton sustain a higher C-specific photosynthetic rate than do smallsized cells. This finding implies that size-differential physiological mechanisms could constitute another feasible alternative to explain the dominance of large phytoplankters under high irradiance and concentrations of sufficient nutrients.

\section{Carbon-specific photosynthesis under light-limited conditions}

The vertical pattern in our measurements of sizefractionated, C-specific photosynthesis revealed an interesting feature. The high $\mathrm{C}$-specific photosynthesis of large-sized phytoplankton observed at the surface showed a sharp decrease with increasing depth, when low light conditions were likely to give rise to the package effect, particularly in larger cells. Different studies have pointed out the size dependence of light absorption and the resulting package effect (Agustí 1991, Finkel 2001, Fujiki \& Taguchi 2002). Finkel (2001) has shown that the chl a-specific absorption coefficient, the quantum yield for photosynthesis and the massspecific photosynthetic rate are all size dependent and that anomalous size-scaling exponents could be due to the package effect under light-limited conditions. In cultures growing under light-limited conditions, she obtained a smaller size-scaling exponent for C-specific photosynthesis than that expected from the 3/4 law, which suggests that large-sized cells are more strongly subjected to pigment packaging. However, her work involved only diatom cultures, whereas in the present study natural, multispecific assemblages were analysed. Following Finkel's conclusion, it is possible that the lack of differences in C-specific photosynthesis between size fractions that we observed in lightlimited conditions could be similarly related to the package effect. It is expected that the physiological advantages enjoyed by large-sized cells in surface waters, under saturated resource conditions, will decrease with depth, as the package effect, which affects small cells less severely (Raven 1998, Raven \& Kübler 2002), becomes a limiting factor for larger phytoplankton.

\section{CONCLUSIONS}

We have shown that large-sized phytoplankton sustain higher C-specific photosynthetic rates than small-sized cells in a productive coastal ecosystem characterised by a diverse phytoplankton community. The higher C-specific photosynthesis in the large size fraction appears to have an important ecological significance, as it represents a physiological basis to explain why large phytoplankters become dominant in resource-saturated environments. In sub-surface waters, the variability in the C-specific photosynthetic rates among the different size fractions becomes weaker or disappears, which might constitute a field evidence for the theoretically predicted package effect. Further studies must be developed in this direction, in order to determine if the higher C-specific photosynthesis by large-sized phytoplankton is a common feature in other aquatic ecosystems under favourable conditions for growth.

Acknowledgements. We thank F. Jiménez and L. Zabala for supplying flow cytometry and image analysis data. We also thank C. G. Castro for nutrient analysis, V. Pérez and P. Serret for their assistance in photosynthesis measurements and 4 anonymous reviewers for valuable comments and suggestions. P.C. was supported by a postgraduate research fellowship from the Spanish Ministry of Science and Technology (MCYT). This research was funded by MCYT through research grant REN2000-1248 to E.M.

\section{LITERATURE CITED}

Agustí S (1991) Allometric scaling of light absorption and scattering by phytoplankton cells. Can J Fish Aquat Sci 48:763-767

Álvarez-Salgado XA, Gago J, Míguez BM, Pérez FF (2001) 
Net ecosystem production of dissolved organic carbon in a coastal upwelling system: the Ría de Vigo, Iberian Margin of the North Atlantic. Limnol Oceanogr 46:35-147

Banse K (1976) Rates of growth, respiration and photosynthesis of unicellular algae as related to cell size - a review. J Phycol 12:135-140

Banse K (1982) Cell volumes, maximum growth rates of unicellular algae and ciliates, the role of ciliates in the marine pelagial. Limnol Oceanogr 27:1059-1071

Banse K (1992) Grazing, temporal changes of phytoplankton concentrations, and the microbial loop in the open sea. In: Falkowski PG, Woodhead AD (eds) Primary productivity and biogeochemical cycles in the sea. Plenum, New York, p 409-440

Blasco D, Packard TT, Garfield PC (1982) Size dependence of growth rate, respiratory electron transport system activity, and chemical composition in marine diatoms in the laboratory. J Phycol 18:58-63

Booth BC (1988) Size classes and major taxonomic groups of phytoplankton at two locations in the subarctic Pacific Ocean in May and August 1984. Mar Biol 97:275-286

Chan AT (1980) Comparative physiological study of marine diatoms and dinoflagellates in relation to irradiance and cell size. II. Relationship between photosynthesis, growth and carbon:chlorophyll a ratio. J Phycol 16:428-432

Chang J, Shiah FK, Gong GC, Chiang KP (2003) Cross-shelf variation in carbon-to-chlorophyll a ratios in the East China Sea, summer 1998. Deep-Sea Res 50:1237-1247

Chisholm SW (1992) Phytoplankton size. In: Falkowski PG, Woodhead AD (eds) Primary productivity and biogeochemical cycles in the sea. Plenum, New York, p 213-237

Crosbie ND, Furnas MJ (2001) Net growth rates of picocyanobacteria and nano-/microphytoplankton inhabiting shelf waters of the central $\left(17^{\circ} \mathrm{S}\right)$ and southern $\left(20^{\circ} \mathrm{S}\right)$ Great Barrier Reef. Aquat Microb Ecol 24:209-224

Falkowski PG, Dubinsky Z, Wyman K (1985) Growth-irradiance relationships in phytoplankton. Limnol Oceanogr 30: 311-321

Fenchel T (1974) Intrinsic rate of natural increase: the relationship with body size. Oecologia 14:317-326

Finkel ZV (2001) Light absorption and size scaling of lightlimited metabolism in marine diatoms. Limnol Oceanogr 46:86-94

Finkel ZV, Irwin AJ, Schofield O (2004) Resource limitation alters the 3/4 size scaling of metabolic rates in phytoplankton. Mar Ecol Prog Ser 273:269-279

Frenette J, Vincent W, Legendre L, Nagata T (1996) Sizedependent phytoplankton responses to atmospheric forcing in Lake Biwa. J Plankton Res 18:371-391

Fujiki T, Taguchi S (2002) Variability in chlorophyll a specific absorption coefficient in marine phytoplankton as a function of cell size and irradiance. J Plankton Res 24:859-874

Furnas ML (1990) In situ growth rates of marine phytoplankton: approaches to measurement, community and species growth rates. J Plankton Res 12:1117-1151

Furnas ML (1991) Net in situ growth rates of phytoplankton in an oligotrophic, tropical shelf ecosystem. Limnol Oceanogr 36:13-29

Geider R, Platt T, Raven JA (1986) Size dependence of growth and photosynthesis in diatoms: a synthesis. Mar Ecol Prog Ser 30:93-104

Grasshoff K, Kremling M, Ehrdardt M (1999) Methods of seawater analysis, 3rd edn. Wiley-VCH, Weinheim

Hashimoto S, Shiomoto A (2002) Light utilization efficiency of size-fractionated phytoplankton in the subarctic Pacific, spring and summer 1999: high efficiency of large-sized diatom. J Plankton Res 24:83-87
Hemmingsen AM (1960) Energy metabolism as related to body size and respiratory surfaces, and its evolution. Rep Steno Mem Hosp 9:15-22

Jochem FJ (2003) Photo- and heterotrophic pico- and nanoplankton in the Mississippi River plume: distribution and grazing activity. J Plankton Res 25:1201-1214

Kiørboe T (1993) Turbulence, phytoplankton cell size and the structure of pelagic food webs. Adv Mar Biol 29:1-72

Kirchman D L (2002) Calculating microbial growth rates from data on production and standing stocks. Mar Ecol Prog Ser 233:303-306

Kirk JTO (1994) Light and photosynthesis in aquatic ecosystems, 2nd edn. Cambridge University Press, Cambridge

Legendre L, Gosselin M, Hirche HJ, Kattner G, Rosenberg G (1993) Environmental control and potential fate of size fractionated phytoplankton in the Greenland Sea $\left(75^{\circ} \mathrm{N}\right)$. Mar Ecol Prog Ser 98:297-313

Li WKW (2002) Macroecological patterns of phytoplankton in the northwestern North Atlantic Ocean. Nature 419: $154-157$

Malone TC (1980) Algal size. In: Morris I (ed) The physiological ecology of phytoplankton. University of California Press, Berkeley, CA, p 433-463

Marañón E, Cermeño P, Fernández E, Rodríguez J, Zabala L (2004) Significance and mechanisms of photosynthetic production of dissolved organic carbon in a coastal eutrophic ecosystem. Limnol Oceanogr 49:1652-1666

Menden-Deuer S, Lessard EJ (2000) Carbon to volume relationships for dinoflagellates, diatoms, and other protist plankton. Limnol Oceanogr 45:569-579

Montagnes DJS, Franklin DJ (2001) Effect of temperature on diatom volume, growth rate, and carbon and nitrogen content: reconsidering some paradigms. Limnol Oceangr 46:2008-2018

Montagnes DJS, Berges JA, Harrison PJ, Taylor FJR (1994) Estimating carbon, nitrogen, protein, and chlorophyll a from volume in marine phytoplankton. Limnol Oceanogr 39:1044-1060

Morel A, Bricaud A (1981) Theoretical results concerning light absorption in a discrete medium, and application to specific absorption of phytoplankton. Deep-Sea Res I 28A:1375-1393

Nogueira E, Pérez FF, Ríos AF (1997) Seasonal patterns and long-term trends in an estuarine upwelling ecosystem (Ría de Vigo, NW Spain). Estuar Coast Shelf Sci 44: 285-300

Paasche E (1960) On the relationship between primary production and standing stock of phytoplankton. J Cons Int Explor Mer 26:33-48

Peters RH (1983) The ecological implications of body size. Cambridge University Press, Cambridge

Raven JA (1997) The vacuole: a cost-benefit analysis. Adv Bot Res 25:59-86

Raven JA (1998) Small is beautiful: the picophytoplankton. Funct Ecol 12:503-513

Raven JA, Kübler JE (2002) New light on the scaling of metabolic rate with the size of algae. J Phycol 38:11-16

Rodríguez J (1994) Some comments on the size-based structural analysis of the pelagic ecosystem. Sci Mar 58:1-10

Rodríguez J, Blanco JM, Jiménez-Gómez F, Echevarría F and 5 others (1998) Patterns in the size structure of the phytoplankton community in the deep fluorescence maximum of the Alboran Sea (southwestern Mediterranean). DeepSea Res I 45:1577-1593

Schaefer CT, Lewin J (1984) Persistent blooms of surf diatoms along the Pacific coast. Mar Biol 83:205-217

Stolte W, McCollin T, Noordeloos AAM, Riegman R (1994) 
Effect of nitrogen source on the size distribution within marine phytoplankton populations. J Exp Mar Biol Ecol 184:83-97

Strathmann RR (1967) Estimating the organic carbon content of phytoplankton from cell volume or plasma volume. Limnol Oceanogr 12:411-418

Taguchi S (1976) Relationship between photosynthesis and cell size of marine diatoms. J Phycol 12:185-189

Tamigneaux E, Legendre L, Klein B, Mingelbier M (1999) Seasonal dynamics and potential fate of size-fractionated phytoplankton in a temperate nearshore environment (western Gulf of St. Lawerence, Canada). Estuar Coast Shelf Sci 48:253-269

Tang EPY (1995) The allometry of algal growth rates. J Plankton Res 17:1325-1335

Taylor AH, Geider RJ, Gilbert FJH (1997) Seasonal and latitudinal dependencies of phytoplankton carbon-to-chloro-

Editorial responsibility: Otto Kinne (Editor-in-Chief), Oldendorf/Luhe, Germany phyll a ratios: results of a modelling study. Mar Ecol Prog Ser 152:51-66

Tilstone GH, Figueiras FG, Fermin EG, Arbones B (1999) Significance of nanophytoplankton photosynthesis and primary production in a coastal upwelling system (Ría de Vigo, NW Spain). Mar Ecol Prog Ser 183:13-27

Verity PG, Robertson CY, Tronzo CR, Andrews MG, Nelson JR, Sieracki ME (1992) Relationships between cell volume and the carbon and nitrogen content of marine photosynthetic nanoplankton. Limnol Oceanogr 37:1434-1446

Welschmeyer NA (1994) Fluorometric analysis of chlorophyll a in the presence of chlorophyll $b$ and phaeopigments. Limnol Oceanogr 39(8):1985-1992

Zubkov M, Sleigh MA, Tarran GA, Burkill PH, Leakey RJG (1998) Picoplankton community structure on an Atlantic transect from $50^{\circ} \mathrm{N}$ to $50^{\circ} \mathrm{S}$. Deep-Sea Res I 45:1339-1355

Submitted: May 2, 2004; Accepted: February 23, 2005 Proofs received from author(s): July 5, 2005 